KS. MIROSŁAW SITARZ

Wydział Prawa, Prawa Kanonicznego i Administracji

Katolickiego Uniwersytetu Lubelskiego Jana Pawła II

\title{
KONCEPCJA ODNOWY MORALNEJ NARODU WEDŁUG PRYMASA TYSIĄCLECIA
}

Treść: Wstęp. - 1. Śluby Jasnogórskie podstawą programu odnowy moralnej Narodu. - 2. Program odnowy moralnej Narodu. - 2.1. Obowiązek wierności Bogu i Kościołowi oraz łasce Chrystusowej. - 2.2. Obowiązek obrony każdego życia. - 2.3. Obowiązek strzeżenia nierozerwalności i świętości małżeństwa i rodziny. - 2.4. Obowiązek dochowania sprawiedliwości społecznej, miłości i pokoju. - 2.5. Obowiązek walki z wadami narodowymi i zdobywanie cnót. - 3. Podsumowanie.

\section{Wstęp}

Koncepcja odnowy moralnej Narodu polskiego została opracowana przez Prymasa Tysiąclecia w trudnych czasach, o których pisał: „Jakże ciężka to była droga, pełna upokorzeń i udręk ... właściwie Polska od 1939 roku cierpi bez oddechu”. U podstaw „tragedii Narodu” - podkreślał Prymas - leży „bezład moralny społeczeństwa”, dlatego współcześnie „słyszy się wielkie wołanie o pow rót moralności ewangelicznej do naszego życia osobistego, rodzinnego i narodowego"2.

\footnotetext{
${ }^{1}$ Cyt. za: P. Raina, Stefan Kardynał Wyszyński Prymas Polski, t. 1, Oficyna Poetów i Malarzy, Londyn 1979, s. 85.

${ }^{2}$ O moralną odnowę Narodu. Do wiernych w bazylice gnieźnieńskiej, 2 II 1981, w: Stefan Kardynał Wyszyński Prymas Polski. Nauczanie społeczne 1946-1981, Ośrodek Dokumentacji i Studiów Społecznych, Warszawa 1990, s. 1007. Szerzej zob. Stefan Kardynał Wyszyński. Jedna jest Polska. Wybór z przemówień i kazań, Wydawnictwo im. Stefana Kardynała Wyszyńskiego „SOLI DEO”, Warszawa 2017.
} 
Program Prymasa Tysiąclecia dotyczący moralnej odnowy Narodu „wyprzedził” ideę Soboru Watykańskiego II i na sposób polski stał się „prawdziwym 'aggiornamento', prawdziwą odnową wiary i moralności Narodu na Millenium”3. Prymas Polski nie tylko trafnie analizował bieżącą sytuację w Narodzie, ale odwołując się do historii, odznaczał się dalekowzrocznością, mówił: „Młode pokolenie Polski idzie w czasy niewątpliwie trudne. Kiedyś mnie zabraknie, ale Wy to przypomnicie! I od Was zażądają wielkich ofiar potężnej wiary, gorącej miłości, a w niejednej klęsce - nadziei na Sprawiedliwego Boga. Musicie być wtedy mężni. W takich momentach pomocą Wam będzie doświadczenie, które Naród zdobył w ciągu minionych dziejów”"

Kardynał Wyszyński podkreślał zadania Kościoła względem Narodu w kontekście służby człowiekowi na płaszczyźnie zbawczej i doczesnej. Fakt ten uzasadniał w sposób następujący: „Chociaż Jezus Chrystus prowadzi nas do Ojca, chociaż nauka Jego jest od Ojca, to jednak prowadzi nas poprzez ziemię, a Jego nauka wywiera wpływ nie tylko na ostateczne sprawy człowieka, ale i na całe życie doczesne. Wcielenie Bożego Syna ma doniosłe znaczenie dla wszystkich spraw ziemskich, doczesnych i może je mocami prawdy ewangelicznej przemieniać, uszlachetniać, nadawać im wymiary Boże, Chrystusowe, religijne, chrześcijańskie, katolickie"' 2 jednej strony, zdaniem S. Wyszyńskiego, Kościół ma do spełnienia określone zadania wyznaczone przez Jego Założyciela, Jezusa Chrystusa zgodnie z nakazem „Idźcie i nauczajcie wszystkie narody...” (Mt 28,19)6,

\footnotetext{
${ }^{3}$ Stefan Kardynał Wyszyński. Biografia w fotografiach, Zakłady Naukowe Seminarium Polskiego, Orchard Lake, Michigan 1969, s. 148.

${ }^{4}$ Słowa te zostały wypowiedziane w Warszawie w dniu 4 października 1970 r., cyt. za: „W Drodze. Miesięcznik poświęcony życiu chrześcijańskiemu” 8 (1981), s. 14.

${ }^{5}$ Aktualność Ślubów Jasnogórskich Narodu. 3 maja 1977 r., w: Stefan kardynał Wyszyński. Głos z Jasnej Góry, Akademia Teologii Katolickiej, Warszawa 1986², s. 404.

${ }^{6}$ Pismo Święte Starego i Nowego Testamentu w przekładzie z języków oryginalnych. Opracował Zespół Biblistów Polskich z inicjatywy Benedyktynów Tynieckich, Pallottinum, Poznań $2008^{5}$.
} 
natomiast z drugiej strony nauczanie oraz uświęcanie człowieka ma istotny wpływ w płaszczyźnie doczesnej.

Prymas Wyszyński fundamentem i jednocześnie podstawą odnowy moralnej Narodu polskiego w sposób szczególny uczynił Jasnogórskie Śluby Narodu. Opracował strategiczny program prowadzący do odnowy moralnej polegający na: 1) wierności Bogu i Kościołowi oraz wierności łasce Chrystusowej, 2) obronie każdego życia, 3) strzeżeniu nierozerwalności i świętości małżeństwa oraz rodziny chrześcijańskiej, 4) strzeżeniu sprawiedliwości społecznej, miłości i pokoju oraz 5) walce z wadami narodowymi i zdobywaniu cnót.

\section{1. Śluby Jasnogórskie podstawą programu odnowy moralnej Narodu}

Prymas Tysiąclecia - przemawiając w dniu 22 maja 1981 r. po raz ostatni do członków Rady Głównej Episkopatu Polski - stwierdził: „Program w Polsce nie może być sztywny. Nasza stałość wyraża się w Credo, wyraża się w Ojcze nasz, w Zdrowaś Maryja, w Ślubach Jasnogórskich, w zawierzeniu, które Ojciec Święty uczynił na Jasnej Górze. A reszta jest płynna. Największą naszą wartością jest wiara naszego ludu, jest przywiązanie do Kościoła, jego więź z Kościołem w Chrystusie i Jego Matce, w waszej wierze, w waszej gorącej miłości i w waszej niezwykłej apostolskiej gorliwości. [...] Wszystkie nadzieje, to Matka Najświętsza. I jeżeli jaki program - to Ona"7. Wyraźnie określił podstawy programu moralnej odnowy Narodu wskazując m.in. na Jasnogórskie Śluby Narodu ${ }^{8}$ i na szczególne miejsce Maryi w Narodzie polskim. Tekst Ślubów został napisany przez kard. Wyszyńskiego w dniu 16 maja 1956 r. w Komańczy, gdzie był więziony ${ }^{9}$,

${ }^{7}$ Z ostatniego przemówienia do członków Rady Głównej Episkopatu Polski [fragment], w: Królowo Polski przyrzekamy, Wydawnictwo im. Stefana Kardynała Wyszyńskiego „SOLI DEO”, Warszawa 2006, s. 171.

${ }^{8}$ Tekst Ślubów zob.: Jasnogórskie Śluby Narodu Polskiego. Rota ślubowań, w: Królowo Polski przyrzekamy, s. 19-22.

${ }^{9}$ Geneza Jasnogórskich Ślubów Narodu. Do górali w Zakopanem, 19 VIII 1957, w: Stefan Kardynał Wyszyński Prymas Polski. Nauczanie społeczne 1946-1981, s. 95-99. Dnia 26 sierpnia 1956 r. przebywając w Komańczy pisał: „[...] przygotowałem 
natomiast uroczyste ślubowanie Narodu odbyło się dnia 26 sierpnia 1956 r. na Jasnej Górze, pod przewodnictwem biskupa Michała Klepacza, ponieważ Prymas w tym czasie był jeszcze internowany. Prymas kochał swój Naród, dlatego tak bardzo zależało Mu na jego odnowie moralnej. Pisał: „Nasza moralna słabość i chwiejność, pomimo silnej wiary, nasz relatywizm moralny, skłonność do ulegania złym przykładom i prądom, posłuch najrozmaitszym błędom, nieraz wprost absurdalnym, upadek moralności małżeńskiej, niewierność, rozwiązłość, nietrzeźwość - to wszystko sprawia, że pion moralno-społeczny Narodu jest tak chwiejny. Umiemy trwać godzinami w świątyniach, stać na placu jasnogórskim, jak stara dąbrowa, ale ulegamy łatwo najsłabszym nawet podnietom do wszystkich grzechów i występków. Jesteśmy duchowo rozdwojeni, rozbici psychicznie, a stąd pozbawiani stylu życia i charakteru narodowego. To wszystko umiemy dziwnie łączyć z naszym przywiązaniem do Kościoła, którego nie słuchamy w codziennym życiu; z naszą gorącą modlitwą, z której nie zbieramy należytych owoców; z naszą czcią do Matki Najczystszej, której tak przeciwne jest nasze życie codzienne. Zwalczać to rozdwojenie, zdobyć pion moralny, nauczyć się zwyciężać siebie, zdobyć męstwo wiary i życia chrześcijańskiego - oto błogosławione dążenia niemal zachowawczego instynktu narodowego i zmysłu katolickiego"10. Tekst Ślubów Jasnogórskich zawiera program moralnej i społecznej odnowy Narodu. Prymas Tysiąclecia znał godność Narodu i jego wartości, ale zdawał sobie sprawę $\mathrm{z}$ „wad narodowych”ll.

w dniu 16 maja tekst Ślubowania, napisałem adoracje stanowe: dla kapłanów, dla młodzieży, dla mężów i matek. Te słowa będą mówiły za mnie do ludzi”, zob. Stefan Kardynał Wyszyński Prymas Polski. Zapiski więzienne, Éditions du Dialogue. Société d'Éditions Internationales, Paris 1982, s. 249.

${ }^{10}$ Każdy kapłan pracuje nad wprowadzeniem w życie Ślubów Jasnogórskich. Referat dla duchowieństwa, w: Stefan Kardynał Wyszyński Prymas Polski. Dzieła zebrane. Tom II 1953-1956. Okres więzienny, red. A. Skarżyńska, Wydawnictwo im. Stefana Kardynała Wyszyńskiego „SOLI DEO”, Warszawa 1995, s. 38.

${ }^{11}$ A. Rastawicka (oprac.), Jasnogórski Komitet Odnowienia Ślubów Narodu. Złoty Jubileusz Ślubów Jasnogórskich 1956-2006, w: Królowo Polski przyrzekamy, s. 179. 
Kardynał Wyszyński był świadomy tego, że „odnowa moralna Narodu” nie nastąpi na skutek jednorazowego wypowiedzenia roty Ślubów. Dlatego też - przygotowując Kościół w Polsce do obchodów Milenium Chrześcijaństwa - zainaugurował Wielką Nowennę, która polegała na wprowadzeniu w życie poszczególnych przyrzeczeń Ślubów, według następującego programu: I Rok (1957/1958) - obrona wiary - „Wierność Bogu, Krzyżowi, Ewangelii, Kościołowi i jego pasterzom”; II Rok (1958/1959) - życie w łasce uświęcającej - „Naród wierny łasce”; III Rok (1959/1960) - obrona życia, zwłaszcza dzieci nienarodzonych - „Życie jest darem Boga”; IV Rok (1960/1961) wierność małżeńska - „Małżeństwo - sakrament wielki w Kościele”; V Rok (1961/1962) - rodzina katolicka - „Rodzina Bogiem silna”; VI Rok (1962/1963) - młodzież - „Młodzież wierna Chrystusowi”; VII Rok (1963/1964) - miłość i sprawiedliwość społeczna - „Abyście się społecznie miłowali”; VIII Rok (1964/1965) - walka z wadami narodowymi - „Nowy człowiek w Chrystusie”; IX Rok (1965) - cześć Najświętszej Maryi Panny - „Weź w opiekę Naród cały”12. Prymas uczynił Jasnogórskie Śluby Narodu programem duszpasterskim dla odnowy moralnej Kościoła w Polsce. Dnia 3 maja 1966 r. podczas centralnej uroczystości obchodów Milenium Chrztu Polski, Prymas Wyszyński wraz z biskupami dokonał Aktu oddania Polski w macierzysta niewolę miłości Maryi za wolność Kościoła w Polsce i w świecie ${ }^{13}$.

Dnia 26 sierpnia 1990 r. papież Jan Paweł II mówił: „Trzeba nam stale wracać do tego Ślubowania, tak jak dawniejsze pokolenia wracały do Ślubów Jana Kazimierza. Trzeba nam stale na nowo ponawiać rachunek sumienia z tych wszystkich zobowiązań, które w nich się zawierają. Są one podstawowe, dotyczą życia Narodu, budują się na

${ }^{12}$ Z.S. JAвŁoŃsKi, Królewskie korzenie Jasnogórskich Ślubów Narodu, w: Królowo Polski przyrzekamy, s. 208. Szerzej na temat komentarza do odnowy moralnej Narodu polskiego zob. Stefan Kardynał Wyszyński. Wypełniamy Jasnogórskie Śluby Narodu. Czytania na maj, Nakładem Jasnej Góry, Warszawa 1957.

${ }^{13}$ Szerzej zob. Historyczny Akt Oddania Nowego Tysiąclecia w macierzyńska niewole Maryi za wolność Kościoła - żywym wotum wdzięczności Narodu. Przed Aktem Oddania Polski podczas uroczystości Tysiąclecia. 3 maja 1966 r., w: Stefan kardynał Wyszyński. Głos z Jasnej Góry, s. 198-202. 
prawie Bożym, które jest zarazem prawem wpisanym w ludzkie sumienie. Prawo to odczytują zarówno wierzący, jak też i niewierzący. Nie co innego też, tylko to moralne prawo winno stanowić rzetelną podstawę ustroju państwa i życia społeczeństwa. Poszanowanie wolności ludzkich sumień to nie co innego jak poszanowanie tego prawa bez którego sumienia są chore i społeczeństwo nie może być zdrowe. W okresie ucisku i skrępowania totalitarnego Kościół przypomniał wszystkim, że w prawie moralnym jest zasadnicza siła oporu i obrony ludzkiej godności. U progu demokracji społeczeństwa obywatelskiego Kościół z tą samą siłą głosi, że to moralne prawo jest warunkiem sprawiedliwego ładu i prawdziwego postępu”" Kontynuował: „Nie przedawniły się te słowa Jasnogórskiego Ślubowania z 1956 roku. Z pewnością się nie przedawniły. [...] Są aktualne w nowych warunkach - i w nowy sposób. Są jeszcze bardziej niż wówczas warunkiem naszej społecznej dojrzałości. Warunkiem naszego miejsca w Europie $[\ldots]^{\prime \prime 15}$.

W celu dokonania odnowy moralnej Narodu i ratowania Jego przyszłości trzeba być świadomym działania „sił światowej demoralizacji” na terenie naszej Ojczyzny. Zadanie to stoi zarówno przed sprawującymi władzę, jak też przed rodzicami, duszpasterzami, nauczycielami i wychowawcami i wszystkimi obywatelami. Prymas podkreślał jednak, że nie można obronić Narodu przed grożącym niebezpieczeństwem bez wstawiennictwa Maryi ${ }^{16}$.

\section{Program odnowy moralnej Narodu}

Odczytując „na nowo” przesłanie Ślubów Jasnogórskich w kontekście odnowy moralnej Narodu, św. Jan Paweł II - kontynuując założenia planu ładu moralnego opracowanego przez Prymasa

\footnotetext{
${ }^{14}$ Jan PAWEŁ II, Jasnogórskie Śluby warunkiem dojrzałości społecznej i naszego miejsca $w$ Europie, w: Królowo Polski przyrzekamy, s. 12.

${ }_{15}$ Tamże, s. 14.

${ }^{16}$ List Episkopatu Polski o poszanowaniu ładu moralnego w życiu Narodu, w: Listy pasterskie Prymasa Polski oraz Episkopatu 1975-1981, Éditions du Dialogue. Société d'Éditions Internationales, Paris 1988, s. 310-311.
} 
Tysiąclecia - przypominał: „Ślubowania Jasnogórskie stanowią program życia Narodu - program Narodu, społeczeństwa, młodzieży który wedle Ślubowań Jasnogórskich chce kształtować swoje życie. [...] Naród sam musi brać w ręce odpowiedzialność za swoje dzieje, za swój byt, za fundamenty tego bytu, za swoją moralność, za swoje wady i cnoty narodowe, społeczne, za swoją kulturę, za każdego człowieka, który się poczyna w łonie matki musi brać odpowiedzialność! I musi znaleźć siłę, żeby tę odpowiedzialność wziąć, żeby jej nie pozwolił sobie wyjąć z rąk!"17. Jan Paweł II zwrócił uwagę, że tekst Ślubów Jasnogórskich nie jest tylko „zabytkiem przeszłości”, ale „warunkiem przyszłości", ponieważ stanowi podstawowy program życia Narodu ${ }^{18}$.

Prymas Tysiąclecia, wskazując na aktualność programu odnowy moralnej Narodu, przypominał o jego istotnych obowiązkach wynikających z chrztu, z życia w Kościele i Narodzie ochrzczonym oraz ze Ślubów Jasnogórskich, tj.: 1) wierności Bogu i Kościołowi oraz łasce Chrystusowej, 2) obrony życia, 3) strzeżenia nierozerwalności i świętości małżeństwa oraz rodziny chrześcijańskiej, 4) strzeżenia sprawiedliwości społecznej, miłości i pokoju, 5) walki z wadami narodowymi i zdobywania cnót ${ }^{19}$.

\subsection{Obowiązek wierności Bogu i Kościołowi oraz łasce Chrystusowej}

Kardynał Wyszyński stwierdził: „Mamy obowiązek wierności Bogu i Kościołowi. [...] I to jest pierwszy nasz obowiązek, który przyjęliśmy na siebie"20. Obowiązek ten - który implikuje odnowę moralną Narodu polskiego - wynika z odpowiedzialności za Kościół wszyst-

\footnotetext{
${ }^{17}$ KardynaŁ Karol WoJtyŁa, Śluby Jasnogórskie programem istotnych wartości $w \dot{z} y c i u$ Narodu, w: Królowo Polski przyrzekamy, s. 155, 157-158.

18 Tamże, s. 157.

${ }^{19}$ Aktualność Ślubów Jasnogórskich Narodu, s. 406.

${ }^{20}$ Tamże, s. 407. „Wzywamy pokornie Twojej pomocy i miłosierdzia w walce o dochowanie wierności Bogu, Krzyżowi i Ewangelii, Kościołowi świętemu i jego pasterzom, Ojczyźnie naszej świętej [...]. Pomnij, Matko Dziewico, przed obliczem Boga na oddany Tobie Naród, który pragnie nadal pozostać królestwem Twoim pod opieką najlepszego Ojca wszystkich narodów ziemi”, zob. Jasnogórskie Śluby Narodu Polskiego, s. 20.
} 
kich, nie tylko hierarchii kościelnej, ale także całego Ludu Bożego. „Doświadczenie bowiem uczy, że niemal wszyscy żywo interesują się tym, co Kościół robi, co mówi, czego wymaga, jak wypełnia swe zadania. Ludzie nieustannie stawiają biskupom i kapłanom swoje wymagania, dają wskazania, i rady, przy czym nie zawsze myślą o tym, co sami powinni czynić, jakie oni mają obowiązki we wspólnocie Ludu Bożego Kościoła"21. Obowiązek zachowywania wierności Bogu i Kościołowi wynika przede wszystkim z racji przyjętego chrztu świętego. W konsekwencji każdy człowiek ochrzczony ponosi odpowiedzialność zarówno w zakresie spraw duchowych, jak i doczesnych. Z obowiązkiem wierności Bogu i Kościołowi korelatywnie związane jest prawo do zachowania wierności Bogu ze strony władz państwowych. Prymas Tysiąclecia podkreślał, że katolicy stanowiący w Polsce ponad $90 \%$ ludności, muszą spotkać się z szacunkiem dla swej wiary i zasad ewangelicznych, dlatego też mają obowiązek domagać się, aby nikt „nie przeszkadzał w wypełnianiu obowiązku wierności Bogu, Kościołowi i Ewangelii Chrystusowej"22. Narzucanie niewiary - mówił Prymas - to jedno z najbardziej szkodliwych zagrożeń moralności Narodu ${ }^{23}$.

Ponadto zdaniem S. Wyszyńskiego, moralna odnowa Narodu nastąpi tylko wówczas, kiedy respektowane będzie - przysługujące wszystkim "dzieciom ochrzczonym Narodu polskiego” - prawo, ale także obowiązek ${ }^{24}$, korzystania z sakramentów świętych, modlitwy

${ }^{21}$ Wezwanie na Wielki Post do odnowy duchowej naszego życia - Człowiek we wspólnocie Kościoła odpowiedzialny za Kościół Chrystusowy, w: Listy pasterskie Prymasa Polski oraz Episkopatu 1975-1981, s. 89.

${ }^{22}$ Aktualność Ślubów Jasnogórskich Narodu, s. 407.

${ }^{23}$ O zagrożeniu moralności Narodu. List pasterski na Wielki Post 1968, w: Stefan Kardynał Wyszyński Prymas Polski. Nauczanie społeczne 1946-1981, s. 343-344; R. Iwan, Prawa, obowiązki i zagrożenia według Prymasa Stefana Wyszyńskiego, Redakcja Wydawnictw KUL, Lublin 1989, s. 49-76.

24 „Przyrzekamy Ci strzec w każdej duszy polskiej daru łaski jako źródła Bożego życia. Pragniemy, aby każdy z nas żył w łasce uświęcającej i był świątynią Boga, aby cały Naród żył bez grzechu ciężkiego, aby stał się Domem Bożym i Bramą niebios dla pokoleń wędrujących poprzez polską ziemię - pod przewodem Kościoła katolickiego - do Ojczyzny wiecznej”, zob. Jasnogórskie Śluby Narodu Polskiego, s. 20. 
prywatnej i publicznej, dostępu do świątyń i posługi kapłanów ${ }^{25}$. „Nikt też - podkreślał Prymas w 1977 r. na Jasnej Górze - nie może zastępować naszej obrzędowości sakramentalnej obrzędowością laicką, która dla katolików i dla chrześcijan nie ma żadnego znaczenia”26. Aktualne pozostają słowa skierowane przez biskupów polskich, iż „w Ojczyźnie naszej trwa zaprogramowana walka ze wszystkim, co pochodzi od Boga, Chrystusa i Jego Kościoła”27. Tak długo, jak w Narodzie polskim będzie brak miłości, Jego odnowa moralna nie będzie mogła zostać zrealizowana, ponieważ „To, co w człowieku najbardziej boskie - miłość, doznało w grzechu pierworodnym bolesnego zakłócenia. Pojawiło się w życiu ludzkim przeciwieństwo miłości - nienawiść, i jej zwyrodnienie - egoizm, a z nim wszystkie grzechy i odejście od rozumnego postępowania w bogatej dziedzinie miłości, z Boga pochodzącej" ${ }^{28}$.

\subsection{Obowiązek obrony każdego życia}

Prymas Tysiąclecia mówił: „Mamy obowiązek obrony życia, i to każdego życia! Obowiązkiem naszym jest zarówno uszanowanie życia nienarodzonych, jak i zachowanie życia tych, którzy wokół nas żyją. [...] Wszystko to wchodzi w zakres obowiązku obrony życia”29.

${ }^{25}$ „Wierni mają prawo otrzymywać pomoce od swoich pasterzy z duchowych dóbr Kościoła, zwłaszcza zaś słowa Bożego i sakramentów”, zob. Codex Iuris Canonici auctoritate Ioannis Pauli PP. II promulgatus (25.01.1983), AAS 75 (1983), pars II, s. 1-317; tekst polski w: Kodeks Prawa Kanonicznego, przekład polski zatwierdzony przez Konferencję Episkopatu, Pallottinum, Poznań 1984, kan. 213.

${ }^{26}$ Aktualność Ślubów Jasnogórskich Narodu, s. 408.

${ }^{27}$ List Episkopatu Polski. Odnawiamy i wypełniamy Jasnogórskie Śluby Narodu, w: Królowo Polski przyrzekamy, s. 148.

${ }^{28}$ List Episkopatu Polski o poszanowaniu ładu moralnego w życiu Narodu, s. 307. Szerzej zob. Naród pełen łaski i prawdy (Kazanie na pierwszą sobotę grudnia [1956]) [Komańcza, przed 13 września 1956], w: Stefan Kardynał Wyszyński Prymas Polski. Dzieła zebrane. Tom II 1953-1956, s. 43-49.

${ }^{29}$ Aktualność Ślubów Jasnogórskich Narodu, s. 408. „[...] odtąd wszyscy staniemy na straży budzącego się życia. Walczyć będziemy w obronie każdego dziecięcia i każdej kołyski równie mężnie, jak ojcowie nasi walczyli o byt i wolność Narodu, płacąc obficie krwią własną. Gotowi jesteśmy raczej śmierć ponieść aniżeli śmierć 
Podkreślał konieczność obrony życia w rodzinie. „W tym prymacie rodziny, tak jak w kołysce, najważniejszy jest prymat życia i obrony życia, gwarancja dla rodzących się Polaków, że ukształtowani mocami Bożymi pod sercami swych matek, będą mogli bezpiecznie w Ojczyźnie Polaków żyć, rozpocząć swoje dzieje, rozwijać je, usłużyć Ojczyźnie i wrócić do Ojca Niebieskiego, z którego wszelkie życie się wywodzi" ${ }^{30}$. Jednym $z$ warunków moralnej odnowy Narodu jest w pierwszej kolejności obrona życia w rodzinie. „Naród rodzi się w kołysce domowej. Jeśli w kołysce domowej nie będzie młodych pokoleń, nie będzie też i Narodu! Naród zaczyna żyć pod sercem matek i Naród zaczyna umierać pod sercem matek. Nasze matki, dające własną krew i ciało, są matkami Narodu. Dlatego też Kościół w Polsce pracuje nad tym, aby rodzina była Bogiem silna, aby istniała należyta cześć dla kobiety-matki, aby zmobilizowano wspólną - nie tylko dwojga rodziców, ale całego Narodu - obronę rodzących się, przychodzących na świat młodych Polaków. Jest to bowiem najważniejszy kapitał naszego życia narodowego ${ }^{31}$. . Nowe życie nie jest nigdy sprawą prywatną rodziców, ale wielkim darem Bożym dla rodziny, a w konsekwencji dla Narodu, Kościoła i całej ludzkości, dlatego nikt nie ma prawa skazywać zwłaszcza „malutkiego" i bezbronnego

zadać bezbronnym. Dar życia uważać będziemy za największą łaskę Ojca wszelkiego życia i za najcenniejszy skarb Narodu", zob. Jasnogórskie Śluby Narodu Polskiego, s. 20-21. Szerzej zob. W obronie życia nienarodzonych (Szkic kazania na pierwsza sobotę stycznia [1957]) [Komańcza, przed 22 września 1956], w: Stefan Kardynał Wyszyński Prymas Polski. Dzieła zebrane. Tom II 1953-1956, s. 50-58.

${ }^{30}$ Odpowiedzialność - obowiązki - prawa w życiu Narodu, w: Stefan kardynał Wyszyński. Kościół w służbie Narodu, oprac. Prymasowski Instytut Ślubów Narodu, Ośrodek „Corda Cordi”, Delegatura Biura Prasowego Episkopatu Polski w Rzymie, Rzym 1981, s. 17.

${ }^{31}$ Milenijne Gody świętego Kościoła łomżyńskiego. Łomża, 7 sierpnia Roku Milenijnego 1966, podczas uroczystej Sumy Tysiąclecia, w: Stefan Kardynał Wyszyński Prymas Polski. Dzieła zebrane. Tom XVII maj-sierpień 1966, red. I. Czarcińska, B. Mackiewicz, A. Rastawicka, Wydawnictwo im. Stefana Kardynała Wyszyńskiego „SOLI DEO”, Warszawa-Częstochowa 2016, s. 361. 
jeszcze człowieka na śmierć32. To człowiek jest najważniejszą wartością na świecie. Wystarczającym argumentem uzasadniającym wartość człowieka - zdaniem Kardynała Wyszyńskiego - jest sam fakt jego istnienia, a to, że jest, implikuje jego prawa i obowiązki ${ }^{33}$.

\subsection{Obowiązek strzeżenia nierozerwalności i świętości małżeństwa i rodziny}

W programie moralnej odnowy Narodu ważne miejsce zajmuje małżeństwo sakramentalne, prawa rodziny, a także zadania względem rodziny, jakie spoczywają na innych podmiotach. Prymas przypominał: „[...] zobowiązaliśmy się do wierności małżeńskiej, aby chronić rodzinę od rozbicia i rozwodów oraz do wychowania młodego pokolenia w duchu chrześcijańskim, zgodnie z prawami rodziny" ${ }^{34}$. Nauczał, że małżeństwo katolickie stanowi „więź Narodu”35. Z nauczania Kardynała Wyszyńskiego - za Cz. Bartnikiem - należy wskazać następujące prawa przysługujące rodzinie: 1) prawo do posiadania dzieci i skierowania świata rodziny ku dziecku w najwyższej miłości; 2) prawo do wzajemnej służby sobie, bez sztucznych ograniczeń i barier; 3) prawo do nierozerwalności węzła małżeńskiego; 4)

\footnotetext{
${ }^{32}$ M. Sitarz, Zadania Kościoła względem Narodu w nauczaniu Prymasa Wyszyńskiego, Roczniki Nauk Prawnych 12 (2002), z. 2, s. 32; Tenże, Posłannictwo Kościoła wobec Narodu w ujęciu Prymasa Polski Stefana Kardynała Wyszyńskiego, w: Kościół a Naród i Państwo w perspektywie 1050. rocznicy Chrztu Polski. Historia i teraźniejszość, red. J. Krukowski, M. Sitarz, I. Dosz, Towarzystwo Naukowe KUL, Lublin 2017, s. 179.

${ }^{33}$ Najważniejszą wartością na świecie jest człowiek. Do Delegacji NSZZ „Solidarność - Mazowsze”, Warszawa, Miodowa, Kaplica Domu Prymasa Polski, 19 X 1980, w: Stefan kardynał Wyszyński. Kościół w służbie Narodu, s. 86.

${ }^{34}$ Aktualność Ślubów Jasnogórskich Narodu, s. 409. „[...] stać na straży nierozerwalności małżeństwa, bronić godności kobiety, czuwać na progu ogniska domowego, aby przy nim życie Polaków było bezpieczne. [...] wychować młode pokolenie w wierności Chrystusowi, bronić je przed bezbożnictwem i zepsuciem i otoczyć czujną opieką rodzicielską”, zob. Jasnogórskie Śluby Narodu Polskiego, s. 21.

${ }^{35}$ Małżeństwo katolickie więzia Narodu ([Kazanie] na druga niedziele po Objawieniu Pańskim [1957]) [Komańcza, przed 22 września 1956], w: Stefan Kardynał Wyszyński Prymas Polski. Dzieła zebrane. Tom II 1953-1956, s. 67-71.
} 
prawo do doskonalenia się poprzez rodzinę i całą rodziną; 5) prawo do miłości, wierności, pełnego zaufania, sprawiedliwości, wolności od podejrzeń, możności otrzymania przebaczenia w przypadku żalu za winy; 6) prawo do pełnej wspólnoty osób, dóbr, myśli, serc, czynów, historii, losów, tworzenia świata; 7) prawo do zgody, pokoju, duchowej „ciszy”, azylu od świata zła i okrucieństwa, wolności od ogólnego zakłamania i zgiełku życia; 8) prawo wolności do samowyrażania swego życia, swobody rozwoju ducha, spełniania swej osobowości rodzinnej; 9) prawo do dobrej sławy rodzinnej, do zachowania i rozwoju tradycji swych ojców, do pamięci rodowej, wspólnego czucia przeszłości rodziny; 10) prawo do tworzenia przez rodzinę jednego wspólnego theatrum vitae, theatrum familiae, niejako wspólnego, czystego ekranu sumienia ${ }^{36}$.

Prymas Tysiąclecia przypominał, że zarówno państwo, jak i Kościół nie są w stanie zastąpić rodziny w pełnieniu przysługujących jej zadań, m.in. w zakresie wychowania ${ }^{37}$. Wypracowując koncepcję moralnej odnowy Narodu polskiego podkreślał jego trudną sytuację: „Jesteśmy w tak trudnym położeniu, że często nie wiemy, jak ubezpieczyć nasz byt narodowy, jakich sił szukać, na jakiej skale się oprzeć. [...] Nie znajdziemy ani dla naszego bytu narodowego, ani dla kultury chrześcijańskiej innego oparcia, jak tylko zdrową rodzinę. Rodzice! Wasza godzina w Polsce nadeszła. Nie myślcie, że kto inny uratuje nasz Naród. Nas uratuje zdrowa rodzina katolicka!"38. Dlatego

\footnotetext{
${ }^{36}$ Cz. BARTnik, Chrześcijańska pedagogia narodowa według Stefana Wyszyńskiego, w: Polska teologia narodu, red. Tenże, Towarzystwo Naukowe KUL, Lublin 1986, s. 189.

${ }^{37}$ Przyrzekamy Ci wychować młode pokolenie w wierności Chrystusowi (Kazanie na pierwsza sobotę lutego [1957]) [Komańcza, wrzesień 1956], w: Stefan Kardynał Wyszyński Prymas Polski. Dzieła zebrane. Tom II 1953-1956, s. 71-77; T. Guz, Troska Sługi Bożego Kardynała Stefana Wyszyńskiego Prymasa Tysiąclecia o chrześcijańskie kształcenie i wychowanie Narodu Polskiego, w: Stefan Wyszyński Prymas Tysiąclecia - absolwent KUL... kandydat na ołtarze, red. M. Sitarz, A. Słowikowska, A. Romanko, Stowarzyszenie Absolwentów i Przyjaciół Wydziału Prawa Katolickiego Uniwersytetu Lubelskiego, Lublin 2017, s. 101-127.

${ }^{38}$ „Rodzice, nadeszła wasza godzina”. Do małżonków katolickich, 15 sierpnia $1961 r$., w: Stefan kardynał Wyszyński. Głos z Jasnej Góry, s. 137.
} 
zachęcał, aby w Polsce obecna była tzw. „ekonomia rodzinna” mająca na celu zaspokajanie potrzeb rodziny, ponieważ to w rodzinach rozwija się Naród ${ }^{39}$.

\subsection{Obowiązek dochowania sprawiedliwości społecznej, miłości i pokoju}

Dochowanie sprawiedliwości społecznej, miłości i pokoju to kolejny niezbędny komponent dokonania odnowy moralnej Narodu ${ }^{40}$. „Można [...] powiedzieć, że od kolebki naszego bytu narodowego Polska wsłuchuje się w pieśń sprawiedliwości i pokoju. Nie zapominamy o tym, że nie brak było w różnych okresach dziejów naszych ciężkich nadużyć i wyzysku, ale zawsze było to odejście od ducha Narodu i od ducha Ewangelii Chrystusowej" ${ }^{\text {41 }}$. Dlatego też obowiązek ten wynika przede wszystkim z odpowiedzialności za zachowanie dziedzictwa Kościoła w Polsce ${ }^{42}$. Jest to odpowiedzialność - na co wielokrotnie zwracał uwagę Kardynał Wyszyński - całego Narodu, Kościoła i wszystkich ludzi. Naród polski, który został wychowany na kulturze chrześcijańskiej, zachodniej, na kulturze łacińsko-rzymskiej, „ma prawo tak się urządzić we własnej Ojczyźnie, aby w Polsce sprawiedliwość była sprawowana w duchu Ewangelii Chrystusowej i wzmacniana przez miłość chrześcijańską. Tylko ta droga prowadzi

\footnotetext{
${ }^{39}$ Uroczystość poświęcenia krzyży, obrazu Matki Bożej Częstochowskiej i konsekracji dzwonów. Bydgoszcz - Wyżyny, 18 IX 1980, w: Stefan kardynał Wyszyński. Kościót w służbie Narodu, s. 52. Szerzej zob. Pokój Boży rodzinie polskiej (Kazanie na pierwsza niedzielępo Trzech Królach [1957]) [Komańcza, przed 22 września 1956], w: Stefan Kardynał Wyszyński Prymas Polski. Dzieła zebrane. Tom II 1953-1956, s. $58-66$.

${ }^{40}$ „[... [ usilnie pracować nad tym, aby w Ojczyźnie naszej wszystkie dzieci Narodu żyły w miłości i sprawiedliwości, w zgodzie i pokoju, aby wśród nas nie było nienawiści, przemocy i wyzysku", zob. Jasnogórskie Śluby Narodu Polskiego, s. 21.

${ }^{41}$ Kroczyć za Słońcem sprawiedliwości, Chrystusem, Bogiem naszym (Kazanie na pierwsza sobotę marca [1957]) [Komańcza, wrzesień 1956], w: Stefan Kardynał Wyszyński Prymas Polski. Dzieła zebrane. Tom II 1953-1956, s. 78.

${ }^{42}$ A. Hauke-Ligowski, Stał na straży naszego duchowego dziedzictwa, W Drodze. Miesięcznik poświęcony życiu chrześcijańskiemu 8 (1981), s. 28-33.
} 
do społecznego pokoju życia i współżycia” ${ }^{43}$. Prymas uczył, jak w sposób właściwy korzystać z dziesięciowiekowego doświadczenia religijnego, które odegrało ogromne znaczenie w życiu Narodu, który jest Narodem ochrzczonym, Narodem katolickim, Narodem rządzącym się Ewangelią.

\subsection{Obowiązek walki z wadami narodowymi i zdobywanie cnót}

Kardynał Wyszyński przedmiotem szczególnej uwagi uczynił: lenistwo, lekkomyślność, marnotrawstwo, pijaństwo i rozwiązłość ${ }^{44}$. W odniesieniu do lenistwa podkreślił, że należy zwalczać lenistwo w postawie duchowej, tak, aby stawiać sobie coraz to większe wymagania, natomiast walka z lekkomyślnością ma na celu poprawę „charakteru narodowego” i brać pełną odpowiedzialność za swoje myśli, słowa i czyny. Marnotrawstwo i pijaństwo sprowadza się do niszczenia sił fizycznych i duchowych, majątku osobistego i narodowego. Z kolei rozwiązłość uboży psychikę i przede wszystkim rozbija rodziny ${ }^{45}$.

Prymas Tysiąclecia nie tylko charakteryzuje wady narodowe, których należy unikać, ale wskazuje, jak należy postępować: „Nie wystarczy przecież odwracać się od złego: trzeba czynić dobrze" ${ }^{36}$ i zdobywać cnoty: wierność, sumienność, pracowitość, oszczędność, wyrzeczenie się samego siebie, wzajemne poszanowanie, miłość i sprawiedliwość społeczna $^{47}$. Walka $\mathrm{z}$ wadami narodowymi i zdobywanie cnót Kar-

\footnotetext{
${ }^{43}$ Aktualność Ślubów Jasnogórskich Narodu, s. 409.

44 „Przyrzekamy wypowiedzieć walkę lenistwu i lekkomyślności, marnotrawstwu, pijaństwu i rozwiązłości”, zob. Jasnogórskie Śluby Narodu Polskiego, s. 21.

${ }^{45}$ Przyrzekamy stoczyć bój z naszymi wadami narodowymi (Kazanie na pierwsza sobotę kwietnia [1957]) [Komańcza, wrzesień 1956], w: Stefan Kardynał Wyszyński Prymas Polski. Dzieła zebrane. Tom II 1953-1956, s. 85-85; Nad zwalczaniem wad społecznych. Wezwanie na Wielski Post 1964, w: Stefan Kardynał Wyszyński Prymas Polski. Nauczanie społeczne 1946-1981, s. 218-226.

${ }^{46}$ Przyrzekamy stoczyć bój z naszymi wadami narodowymi, s. 85.

${ }^{47}$ „Przyrzekamy zdobywać cnoty: wierności i sumienności, pracowitości i oszczędności, wyrzeczenia się siebie i wzajemnego poszanowania, miłości i sprawiedliwości społecznej”, zob. Jasnogórskie Śluby Narodu Polskiego, s. 21.
} 
dynał Wyszyński określił jako zadanie „najświętsze” i „najcięższe”, ponieważ jest to bój toczony z samym sobą, w myślach, sercu i woli. „Łatwo jest zwalczać nieprzyjaciół. Ale siebie pokonać? A przecież największym bohaterem jest ten, kto siebie, a nie innych zwalczył. Zwycięstwo nad innymi może być często początkiem klęski. Ale zwycięstwo nad sobą jest zawsze początkiem chwały: i na ziemi, i w niebie"48. Ponadto Kardynał Wyszyński nawoływał, że nie można mówić o odnowie moralnej Narodu bez odwołania się do sumienia osoby ludzkiej, sumienia rodzinnego, sumienia narodowego, sumienia zawodowego i sumienia obywatelsko-politycznego ${ }^{49}$.

\section{Podsumowanie}

Podsumowując koncepcję odnowy moralnej Narodu wypracowaną przez Prymasa Tysiąclecia należy przypomnieć słowa tego Wielkiego Człowieka Kościoła, ale przede wszystkim Wielkiego Polaka, który tak bardzo ukochał swoją Ojczyznę: „Niech każdy z nas z większą gorliwością podejmie pracę nad religijno-moralną odnową Narodu. Wprawdzie pojedynczy człowiek niewiele może uczynić, jednak nie rezygnujemy ze swego choćby maleńkiego udziału w wypełnianiu słowa danego Królowej Polski. Może ktoś z Was uratuje tylko jedno nienarodzone dziecko, może wasza rodzina przyjmie i wychowa po katolicku jeszcze jednego Polaka, a może ktoś już nigdy nie nadużyje alkoholu. Gdy ktoś z nas lepszy się stanie, lepszy stanie się Naród, piękniejszy stanie się Kościół i my bardziej do Boga podobni” ${ }^{50}$. Program moralnej odnowy Narodu Kardynała Wyszyńskiego zakładał respektowanie obowiązków i praw, które mają podstawę w chrzcie oraz życiu w Kościele i Narodzie, tj. 1) wierności Bogu i Kościołowi oraz łasce Chrystusowej, 2) obronie życia, 3) strzeżenia nierozerwal-

\footnotetext{
${ }^{48}$ Przyrzekamy stoczyć bój z naszymi wadami narodowymi, s. 86.

${ }^{49}$ Sumienie prawe u podstaw odnowy życia narodowego. Do wiernych $w$ archikatedrze warszawskiej, 6 I 1981, w: Stefan Kardynał Wyszyński Prymas Polski. Nauczanie społeczne 1946-1981, s. 986-995.

${ }^{50}$ List Episkopatu Polski. Odnawiamy i wypetniamy Jasnogórskie Śluby Narodu, s. 148.
} 
ności i świętości małżeństwa oraz rodziny chrześcijańskiej, 4) strzeżenia sprawiedliwości społecznej, miłości i pokoju, 5) walki z wadami narodowymi i zdobywaniu cnót.

\section{The concept of the moral renewal of the Nation according to Primate of the Millennium}

Stefan Cardinal Wyszyński in the program of the moral renewal of the Nation assumed respecting for the obligations and rights that are based on baptism and the life in the Church and in the Nation, i.e. 1) the fidelity to God and the grace of Christ, 2) to defend life, 3) to safeguard the indissolubility and sanctity of marriage and the family Christianity, 4) safeguarding social justice, love and peace, 5) combating national flaws and gaining virtues.

SŁOWA KLUCzowe: Kościół; Naród; Państwo; prawa i obowiązki; rodzina

KEY WORDS: Church; Nation; State; rights and obligations; family

\section{Nota o Autorze:}

Ks. Dr hab. Miroseaw Sitarz, prof. KUL - kierownik Katedry Kościelnego Prawa Publicznego i Konstytucyjnego KUL, Wydział Prawa, Prawa Kanonicznego i Administracji, Katolicki Uniwersytet Lubelski Jana Pawła II. 